\title{
Seedling production of Bertholletia excelsa in response to seed origin and position inside fruit
}

\author{
Luiz Fernandes Silva Dionisio ${ }^{\oplus}$, Edgar Cusi Auca ${ }^{\oplus}$, Gustavo Schwartz ${ }^{3}$, Ricardo Manuel Bardales-Lozano ${ }^{4} \oplus$, \\ Jimmy Jeanine Miró Agurto²®, Ronald Corvera-Gomringer²,

\footnotetext{
1 Universidade do Estado do Pará, Belém, PA, Brazil. E-mail: fernandesluiz03@gmail.com

${ }^{2}$ Instituto de Investigaciones de la Amazonia Peruana, Puerto Maldonado, Peru. E-mail: ecusi@iiap.org.pe; miroagurto@yahoo.es; rcorvera@iiap.org.pe

${ }^{3}$ Embrapa Amazônia Oriental, Belém, PA, Brazil. E-mail: gustavo.embrapa@gmail.com

${ }^{4}$ Empresa Palmas del Espino S.A, Madre de Dios, Peru. E-mail: rbardaleslozano@gmail.com
}

ABSTRACT: Bertholletia excelsa, known as Brazil nut, is an economically valuable tree species from the Amazon. Seeds of $B$. excelsa figure as one of the most important non-timber forest products in Bolivia, Brazil, and Peru. These seeds, however, have physiological dormancy, which makes the germination slow, irregular, and often in low percentages. Such biological feature represents a bottleneck to the production of high quality seedlings. In an experiment performed in Puerto Maldonado, Peru, ten fruits were collected per individual in 15 trees of $B$. excelsa in each of the two areas: an experimental planting and a native forest. Several variables regarding fruit biometry, germination, initial growth, and seedlings quality indexes were measured in order to compare $B$. excelsa seedlings produced by seeds from two areas and also regarding the lower and upper seed position inside the fruit. Both fruit length and diameter presented low variation and most of the fruits had flat shape. Seeds were more abundant in the lower position (mean $=12.9 \pm 2.2$ ) than in the upper position (mean $=6.5 \pm 2.1$ ) inside the fruit. Considering the total number of seeds per fruit, the means were $19.4 \pm 3.2$ and $17.5 \pm 3.7$ for planted and native forest, respectively. Complete germination did not differ between areas $\left(F_{1,56}=1.945, p=0.169\right)$. Seedlings produced with seeds from planted and from the lower position inside the fruit presented higher quality indexes.

\section{Produção de mudas de Bertholletia excelsa em resposta a origem} da semente e posição no interior do fruto

RESUMO: Bertholletia excelsa, conhecida como castanha-do-brasil, é uma espécie arbórea economicamente valiosa na Amazônia. Sementes de B. excelsa aparecem como um dos produtos florestais não-madeireiros mais importantes na Bolívia, Brasil e Peru. No entanto, estas sementes possuem dormência fisiológica, o que torna a germinação lenta, irregular e frequentemente em baixas percentagens. Tal característica biológica representa um gargalo para a produção de mudas de alta qualidade. Em um experimento em Puerto Maldonado, Peru, dez frutos foram coletados por indivíduo em 15 árvores de $B$. excelsa em cada uma de duas áreas: um plantio experimental e uma floresta nativa. Várias variáveis relacionadas à biometria de frutos, germinação, crescimento inicial e índices de qualidade de mudas foram mensuradas no sentido de comparar mudas de $B$. excelsa produzidas por sementes originadas de duas áreas e também quanto à posição de sementes no fruto, inferior e superior. Comprimento e diâmetro do fruto apresentaram baixa variação e a maioria dos frutos teve forma achatada. As sementes foram mais abundantes na posição inferior (média $=12,9 \pm 2,2$ ) do que na posição superior (média $=6,5 \pm 2,1$ ) no interior do fruto. Considerando o número total de sementes por fruto, as médias foram 9,4 $\pm 3,2$ e 17,5 $\pm 3,7$ para floresta plantada e nativa, respectivamente. A germinação completa não diferiu entre as áreas $\left(\mathrm{F}_{1,56}=1,945, p=0,169\right)$. Mudas produzidas com sementes de plantios e da posição inferior no interior do fruto apresentaram maiores índices de qualidade.

Palavras-chave: castanha-do-pará; índices de qualidade; germinação de sementes; produção de mudas florestais 


\section{Introduction}

Bertholletia excelsa Humb. and Bonpl. (Lecythidaceae), known as Brazil nut, is a tree species with great economic importance in the Amazon region (Santos et al., 2017). Seeds of $B$. excelsa figure as one of the main non-timber forest products of extractive activities in Bolivia, Brazil, and Peru (Costa et al., 2017; Wadt et al., 2018). Nonetheless, due to exploitation pressures and habitat fragmentation of $B$. excelsa (Sujii et al., 2015), the studies on seedling production aiming reforestation, management, and species conservation become fundamental.

Tree planting has been the primary way of achieving artificial regeneration of tropical forests over the past six decades. As concerns about global deforestation increase, planting programs will also increase in order to mitigate potential climate changes. This emphasis on tree planting has focused renewed attention on identifying those seedling attributes still in the nursery, which can predict the establishment success. A simple, easy-to-measure index of these seedling attributes is needed. Nursery managers also need reliable seedling indexes to make management decisions during the growing season, especially during the critical seedling harvesting season. These seedling attributes, necessary for reforestation success, have been collectively defined as "seedling quality." For reforestation purposes, seedling quality can be defined as those attributes required for a given seedling to survive and grow after planted in the field (Duryea, 1985).

Morphological characteristics, such as seedling size, have been used traditionally to score seedling quality in the nursery and match seedlings to the environmental conditions found in the field. Production of forest species seedlings is one of the most important activities in reforestation, since low seedling quality can compromise the success of subsequent populations. A quality seedling should have characteristics that provide a high chance of survival and rapid initial growth in the field. The morphological parameters most be used to determine indexes of seedling quality. This help to avoid a complete rely on intuitive understanding from nurserymen on seedlings quality (Auca et al., 2018).

A high quality seedling must present features that permit maximum survival rates and high initial growth once planted in the field. Morphological parameters are the most used to determine indexes of seedlings quality, since they are easily understood by nursery workers. To attain the minimum values of these indexes in each tree species, it is necessary to know the recipient size and volume, the correct matter management, fertilizing, and the solar radiation control (Marana et al., 2015). One of the most important ways of tree seedling production is through sexual reproduction, where germination represents a crucial phase influenced by temperature, substrate, wetness, luminosity, seed position on the seedbed, and sowing depth (Cosmo et al., 2017). Moreover, B. excelsa seeds present physiological dormancy, which results in slow, irregular, and low percentages of germination (Kainer et al., 1999a; Auca et al., 2018). Seed burial depth and food reserves within seeds are the most important factors affecting seed germination (Tanveer et al., 2013; Baskin \& Baskin, 2014).

Germination is a key stage that can be influenced by silvicultural propagation methods. When producing forest species seedlings for reforestation, it is essential to study techniques that enhance seed germination and produce quality seedlings at the lowest cost (Auca et al., 2018). Temperature usually is considered as the main determinant of germination, when other factors are not limiting (Tanveer et al., 2012). Light may also be a critical factor for germination, but some species are insensitive to either light or dark, others are inhibited by light exposure and germinate more readily under darkness (Ali et al., 2013; Batlla \& Benech-Arnold, 2014). Moisture stress may delay, reduce, or prevent germination of most seeds.

The morphological and physiological quality of seedlings before planting in the field are features that depend on the seed origin, employed production methods, substrates, production management, environmental conditions, equipment, and nursery structure (Caron et al., 2010). Besides these factors, origin and position of seeds in the fruit can influence germination and consequently the quality of the seedlings. Ecological information on germination of tree species is important for managers to know the potential of these species in growing under different agro-ecological conditions. Such information is essential to maximize efficiency of planting (Ebrahimi \& Eslami 2012).

The objective of this work was to evaluate fruit biometry, emergence, and initial growth of $B$. excelsa in relation to origin and seed position inside fruits. Thus, the following scientific question is presented: Are emergence and seedlings quality of $B$. excelsa influenced by their origin and seed position inside fruits?

\section{Material and Methods}

Study area, collection, and biometry of Bertholletia excelsa fruits

Experimental procedures were conducted in the nursery of the Research Institute of the Peruvian Amazon (IIAP), in Puerto Maldonado district, Madre de Dios department, Peru (2 $\left.49^{\prime} 11^{\prime \prime} \mathrm{N}, 60^{\circ} 40^{\prime} 24^{\prime \prime} \mathrm{W}\right)$. Research activities were carried out under the project coordinated by IIAP "Increase of the technological and genetics knowledge of Brazil nut (Bertholletia excelsa) aiming its domestication in Madre de Dios region, Peru".

Fruits of Bertholletia excelsa were collected in two areas: a) an experimental planting and b) a native forest, both belonging to IIAP in Puerto Maldonado. The collection was done from January to March 2018, where 15 trees were selected per area. Ten fruits per tree were collected, totaling 150 fruits per area. After collection, fruits were transferred to the laboratory where biometric evaluations were carried out. Each fruit was measured in: a) length $(\mathrm{cm})$, b) diameter $(\mathrm{cm})$, mesocarp thickness $(\mathrm{cm})$, weight $(\mathrm{g})$, and number of seeds in relation to their position in the fruit (upper and lower position). 
Fruits were also classified in relation to their hardness (low, medium, and high) and shape (flat, elliptical, and round). The fruit hardness classification was determined intuitively by only one person, who alone opened all fruits. In spite of this, results of such variables were presented only in a descriptive and qualitative way. Seeds were manually extracted from fruits with a machete and their integument was removed with a lathe to avoid damage. The germination experiment was conducted immediately after the seeds extraction from fruits. Seeds were treated with the fungicide Vitavax -300 (carboxin $200 \mathrm{~g} / \mathrm{kg}+$ capitan $200 \mathrm{~g} / \mathrm{kg}$ ) and sowed in seedbeds with washed sand as substrate. The seeds were covered by a sand layer with their germination pores buried at $2 \mathrm{~cm}$ depth. The substrate wetness was maintained by daily irrigation.

After germination, seedlings were transplanted and grown in small $115 \mathrm{~cm}^{3}$ small tubes (Auca et al., 2018), filled with a substrate composed by forest soil + sawdust + charred sawdust, all in the same proportion $(1: 1: 1 \mathrm{v} / \mathrm{v})$. This substrate had its physical and chemical features analyzed (Table 1).

The seedlings were watered and, before being transplanted to the small tubes, those with defective root systems were phased out. The transplanting process was carried out under a roof, in a shaded and fresh environment. All seedlings were maintained in a recipient with water since they were taken out the seedbed to avoid stress. Seedlings growth was monitored during 180 days (June-November 2018). During the growth evaluation, the small tubes were maintained in greenhouses under $50 \%$ of shading. Temperature and wetness were not controlled, but the same conditions were kept for different treatments. Throughout the production process of seedlings, the mean temperature was $28.3{ }^{\circ} \mathrm{C}$ while the minimum and maximum temperatures were $20.9{ }^{\circ} \mathrm{C}$ and $38.7{ }^{\circ} \mathrm{C}$, respectively. The mean wetness was $88.6 \%$ with minimum of $49.7 \%$ and maximum of $99.9 \%$. In order to assess temperature and wetness, a Datalogger model $A Z^{\circ} 88162$ was used.

\section{Seedling emergence and initial growth}

Differences in seedling germination and growth were compared between the treatments of planted and native forest. For this experiment, a total of 750 seeds were taken randomly from the 150 fruits collected in each area (total of 1500 seeds) and then were assessed in relation to complete and incomplete germination. Two treatments were used with five replicates of 150 seeds each. The germination was monitored during 180 days, with it being considered as complete when both root and shoot are formed and incomplete when root and/or shoot are not formed. Seedlings initial growth was evaluated by the measurements of the variables: a) leaves number, b) stem collar diameter, c) shoot length, d) root length, e) shoot dry mass, f) root dry mass, g) total dry mass, h) shoot dry mass/root dry mass relation (SDM/RDM), i) slenderness index, j) lignification index, and k) Dickson quality index (DQI). Higher DQI values as well as the lignification and slenderness indexes indicate higher seedlings quality. The stem collar diameter was measured with a digital caliper (precision $=0.01 \mathrm{~mm}$ ), and shoot and root lengths were measured with a ruler graded in millimeters. To measure dry mass, seedlings were split in shoots and roots by a cut at the stem collar. Both parts were put separately in Kraft paper bags, identified, and dried in an oven at $65{ }^{\circ} \mathrm{C}$ for 48 hours up to it reaching a constant mass. Finally, samplings were weighted in an analytical balance (precision $=0.001 \mathrm{~g}$ ) to obtain shoot and root dry masses.

Shoot dry mass/root dry mass relation (SDM/RDM) reflects the development of plants in nursery and it is determined by the Equation 1.

$$
\mathrm{SDM} / \mathrm{RDM}=\frac{\text { Shoot dry mass }(\mathrm{g})}{\text { Root dry mass }(\mathrm{g})}
$$

The Slenderness index (SI) was calculated, as the ratio between shoot height and root collar diameter, which is given by the Equation 2 .

$$
\mathrm{SI}=\frac{\text { Shoot height }}{\text { Root collar diameter }(\mathrm{mm})}
$$

Lignification index (LI) relates the total dry mass with the total wet mass of the plant, which determines the lignification percentage and it is given by the Equation 3.

$$
\mathrm{LI}=\left(\frac{\text { Total dry mass }(\mathrm{g})}{\text { Total wet mass }(\mathrm{g})}\right) \times 100
$$

In order to determine DQI, seedlings were separated from shoots and roots and not considered as part of the total dry mass (Siqueira et al., 2018). DQI was calculated through the Equation 4.

$$
\text { DQI }=\frac{\text { Total dry mass }(\mathrm{g})}{\frac{\text { Shoot length }(\mathrm{cm})}{\text { Stem collar diameter }(\mathrm{mm})}+\frac{\text { Shoot dry mass }(\mathrm{g})}{\text { Root dry mass }(\mathrm{g})}}
$$

\section{Data analysis}

The experimental design applied in this study was fully randomized with a $2 \times 2$ factors (seed origin $\times$ seed

\begin{tabular}{|c|c|c|c|c|c|c|c|}
\hline Feature & $\mathrm{pH}$ & $\begin{array}{c}E C \\
\left(\mathrm{dS} \mathrm{m}^{-1}\right)\end{array}$ & $\begin{array}{l}\text { FC } \\
(\%)\end{array}$ & $\begin{array}{c}\mathrm{SD} \\
\left(\mathrm{g} \mathrm{cm}^{-3}\right)\end{array}$ & $\begin{array}{c}\text { PD } \\
\left(\mathrm{g} \mathrm{cm}^{-3}\right)\end{array}$ & $\begin{array}{l}\text { TP } \\
\text { (\%) }\end{array}$ & MP \\
\hline Value & 6.30 & 0.70 & 67.47 & 0.50 & 1.44 & 65.51 & 5.04 \\
\hline
\end{tabular}

Table 1. Physical and chemical features of the substrate used to grow experimentally Bertholletia excelsa seedlings: Hydrogen potential $(\mathrm{pH})$, electric conductivity $(\mathrm{EC})$, field capacity $(\mathrm{FC})$, soil density (SD), particles density (PD), total porosity (TP), and macroporosity (MP). 
position inside the fruit). Data were initially tested on residual normality by the Shapiro-Wilk test $(p>0.05)$ and variance homogeneity by the Bartlett test $(p>0.05)$. The independence between experimental units was also checked to fulfill requirements for the analysis of variance (ANOVA). Means differences between treatments were compared by using the $F$ test $(p<0.05)$. Analyses were run with the software $R$, version 3.5.2.

\section{Results}

\section{Fruit biometry and number of seeds per fruit}

Bertholletia excelsa fruits from the native forest were significantly larger in length, diameter, mesocarp thickness, and weight in relation to the planted forest (Table 2). There was a significant difference in the number of seeds in relation to their position in the fruit. Seeds were more abundant in the lower position (mean $=12.9 \pm 2.2$ ) than in the upper position $($ mean $=6.5 \pm 2.1$ ).

Fruits originated from the native forest had a mean of 11.9 \pm 2.8 and $5.6 \pm 2.3$ seeds in the lower and upper seed position inside the fruit, respectively. For the total number of seeds per fruit, the means were $19.4 \pm 3.2$ and $17.5 \pm 3.7$ for planted and native forest, respectively (Figure 1 ).

Fruits originated from the native forest presented higher hardness, which varied from medium to high. On the other hand, fruits from the planted forest had hardness varying from low to medium (Figure 2A). In relation to fruit shape, fruits from both origins presented higher number of flat fruits (Figure 2B).

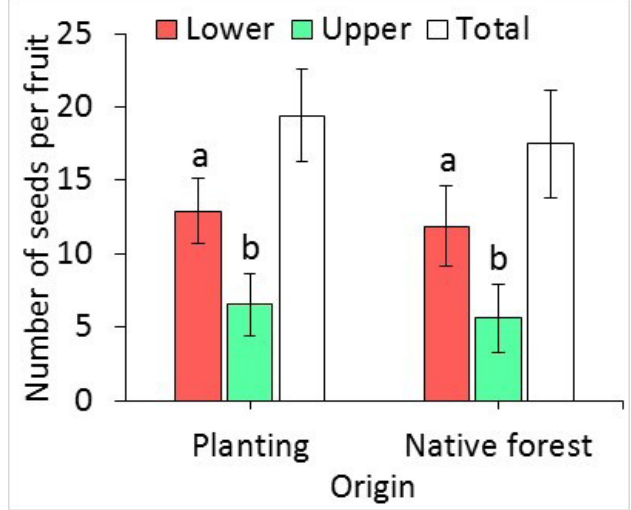

Figure 1. Mean $( \pm S D)$ number of Bertholletia excelsa seeds per fruit, in the lower, and in the upper position inside the fruits originated from planting and native forest, Puerto Maldonado, Peru. Letters indicate significant differences $(p<$ 0.05 ) in ANOVA with the $F$ test.

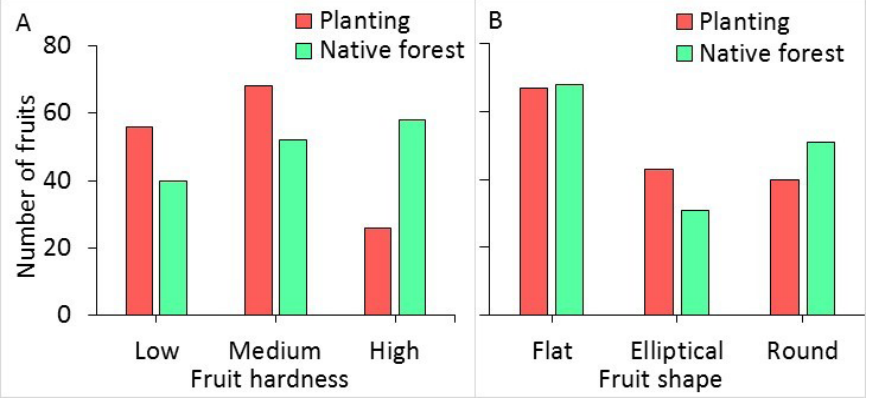

Figure 2. Number of Bertholletia excelsa fruits in relation to their hardness and shape in Puerto Maldonado, Peru.

\section{Seedling emergence and initial growth}

Germination started at 30 days after sowing and stabilized at 160 days. Time distribution of germination for fruits both from planted and native forests followed polynomial curves (Figures $3 \mathrm{~A}$ and $3 \mathrm{~B}$ ).

In relation to origin, there were no significant difference for complete germination $\left(F_{1,56}=1.945, p=0.169\right)$ and incomplete germination $\left(F_{1,56}=1.493, p=0.226\right)$. B. excelsa seeds presented $67 \%$ of complete germination, $22 \%$ of incomplete germination. The number of leaves differed only for seeds from the planted $\left(F_{1,56}=6.560, p=0.0132\right.$, Figure $4 A)$, but not in the stem collar diameter $\left(F_{1,56}=2.385, p=\right.$ 0.128 , Figure $4 \mathrm{~B})$ and shoot length $\left(\mathrm{F}_{1,56}=0.200, p=0.656\right.$, Figure $4 C$ ) in relation to origin and seed position inside the fruit. The root length showed significant difference in relation to origin $\left(F_{1,56}=12.439, p=0.001\right)$ and position $\left(F_{1}\right.$ $\left.{ }_{56}=42.648, p=0.001\right)$. Seedlings produced from seeds of the lower position in the fruits presented higher root length in both planting $(21.6 \pm 1.9)$ and native forest $(19.9 \pm 2.2)$ (Figure 4D).

Shoot dry mass had no statistical difference when compared to the seed position inside fruit $\left(F_{1,56}=1.673, p=\right.$ 0.201 , Figure $5 A$ ). Seedlings produced from seeds of the lower position in the fruit had the highest root dry mass in both cases: originated from planted $\left(0.4 \pm 0.1 \mathrm{~g}, \mathrm{~F}_{1,56}=9.125, p=\right.$ $0.004)$ and native forest $\left(0.3 \pm 0.1 \mathrm{~g}, \mathrm{~F}_{1,56}=5.058, p=0.028\right.$, Figure $5 \mathrm{~B}$ ). It was also observed a statistical difference in the shoot dry mass/root dry mass (SDM/RDM) relation $\left(F_{1,56}=\right.$ $7.667, p=0.008$ ). Seeds from the upper position inside fruits presented higher mean in the SDM/RDM relation regarding the lower position for seeds originated both from planting $(7.4 \pm 1.0 \mathrm{~g})$ and native forest $(7.3 \pm 0.6 \mathrm{~g}$, Figure $5 \mathrm{C})$. The total dry mass did not present significant difference in relation to origin and seed position inside the fruit $\left(\mathrm{F}_{1,56}=2.454, p=\right.$ 0.123 , Figure 5D).

Table 2. Mean $( \pm S D$ ) of length, diameter, thickness, and weight of Bertholletia excelsa fruits originated from planting and native forest in Puerto Maldonado, Peru.

\begin{tabular}{|c|c|c|c|c|}
\hline \multirow{2}{*}{ Origin } & Length & Diameter & \multirow{2}{*}{$\begin{array}{l}\text { Thickness } \\
\text { (mm) }\end{array}$} & \multirow{2}{*}{$\begin{array}{c}\text { Weight } \\
\text { (g) }\end{array}$} \\
\hline & & & & \\
\hline Planting & $10.1 \pm 0.9 a$ & $10.4 \pm 0.6 \mathrm{a}$ & $9.8 \pm 1.7 \mathrm{a}$ & $439.8 \pm 88.0 a$ \\
\hline Native forest & $12.9 \pm 1.0 \mathrm{~b}$ & $11.3 \pm 1.1 b$ & $11.5 \pm 1.7 b$ & $571.6 \pm 133.5 b$ \\
\hline
\end{tabular}

Letters indicate statistical differences $(p<0.05)$ in ANOVA and the Tukey post-hoc test. 

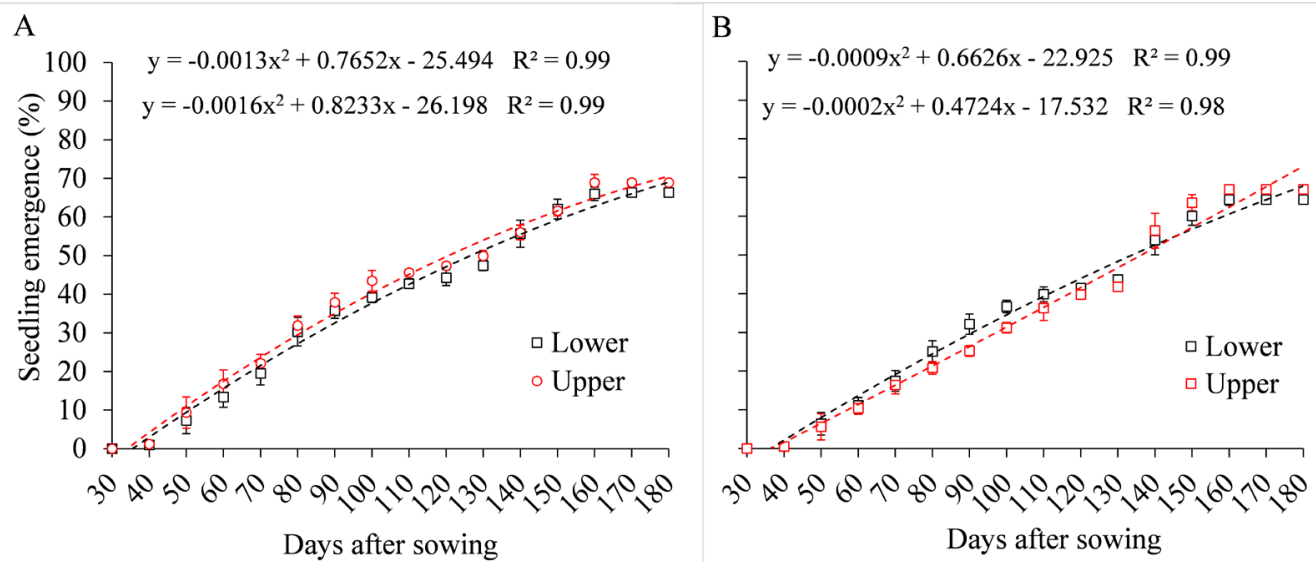

Figure 3. Accumulated curves of seedlings emergence of Bertholletia excelsa in relation to: origin (A) and seed position inside fruits (B) in Puerto Maldonado, Peru.

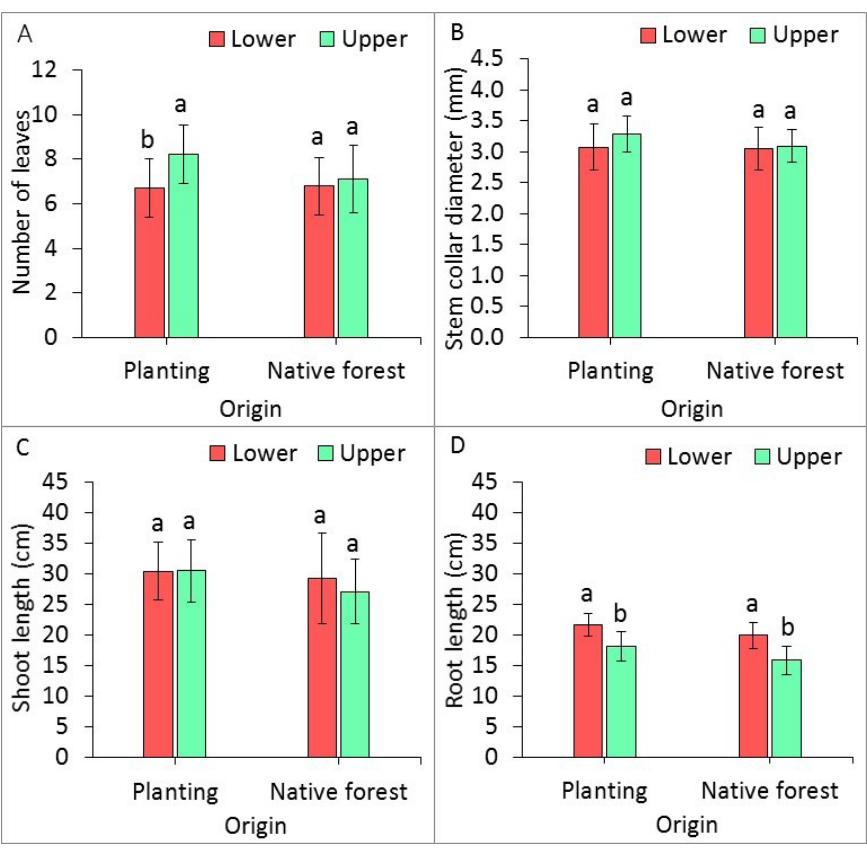

Figure 4. Mean ( $\pm S D$ ) of the number of leaves $(A)$, stem collar diameter (B), shoot length (C), and root length (D) of Bertholletia excelsa seedlings originated from planting and native forest at 180 days after sowing in Puerto Maldonado, Peru. Letters indicate significant differences $(p<0.05)$ in ANOVA with the $\mathrm{F}$ test.

\section{Seedlings quality indexes}

No significant differences were found in relation to origin and seed position inside the fruit for the variables lignification index $\left(F_{1,56}=1.832, p=0.181\right.$, Figure $\left.6 \mathrm{~A}\right)$ and slenderness index $\left(F_{1,56}=2.784, p=0.101\right.$, Figure 6B). The Dickson quality index (DQI) presented significant difference in seed position inside fruits only in those coming from the planted forest $(0.16 \pm$ $0.04, \mathrm{~F}_{1,56}=5.168, p=0.026$, Figure $\left.6 \mathrm{C}\right)$.

\section{Discussion}

\section{Fruit biometry and number of seeds per fruit}

Fruit length and diameter of Bertholletia excelsa presented low variation, but most of the fruits had flat shape (Figure $2 \mathrm{~B}$ ).

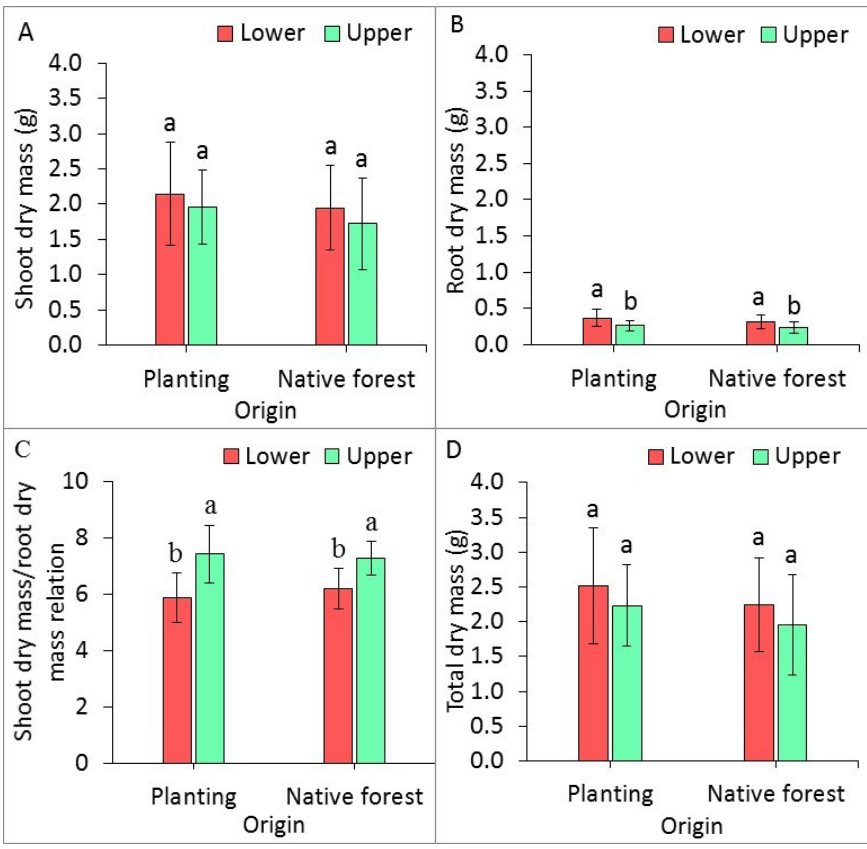

Figure 5. Mean $( \pm S D)$ of shoot dry mass $(A)$, root dry mass (B), shoot dry mass/root dry mass relation (C), and total dry mass (D) of Bertholletia excelsa seedlings originated from planting and native forest at 180 days after sowing. Letters indicate significant differences $(p<0.05)$ in ANOVA with the F test.

The mean of mesocarp thickness from planting fruits $(8.9 \mathrm{~cm})$ was similar to the mean found by Borella et al. (2017) in Mato Grosso state, Brazil. The fruit weight mean found in this study $(571.6 \mathrm{~g})$ was similar to the results of Rocha et al. (2016), who observed $425.27 \mathrm{~g}$ in average. Different authors, however, report great variation in fruit weight of $B$. excelsa, from 154.32 to $817.69 \mathrm{~g}$ (Borges et al., 2016, Rocha et al., 2016). The mean number of seeds per fruit (17.5) found in this study corroborates the results of Salomão et al. (2006), Borges et al. (2016), Rocha et al. (2016), Borella et al. (2017), and Pedrozo et al. (2017) in different regions of the Brazilian Amazon. These authors report means of $16.0,17.0,16.6,17.5$, and 17.0 seeds per fruit, respectively. The variation in seeds quantities per fruit is directly influenced by biological factors of the matrix 


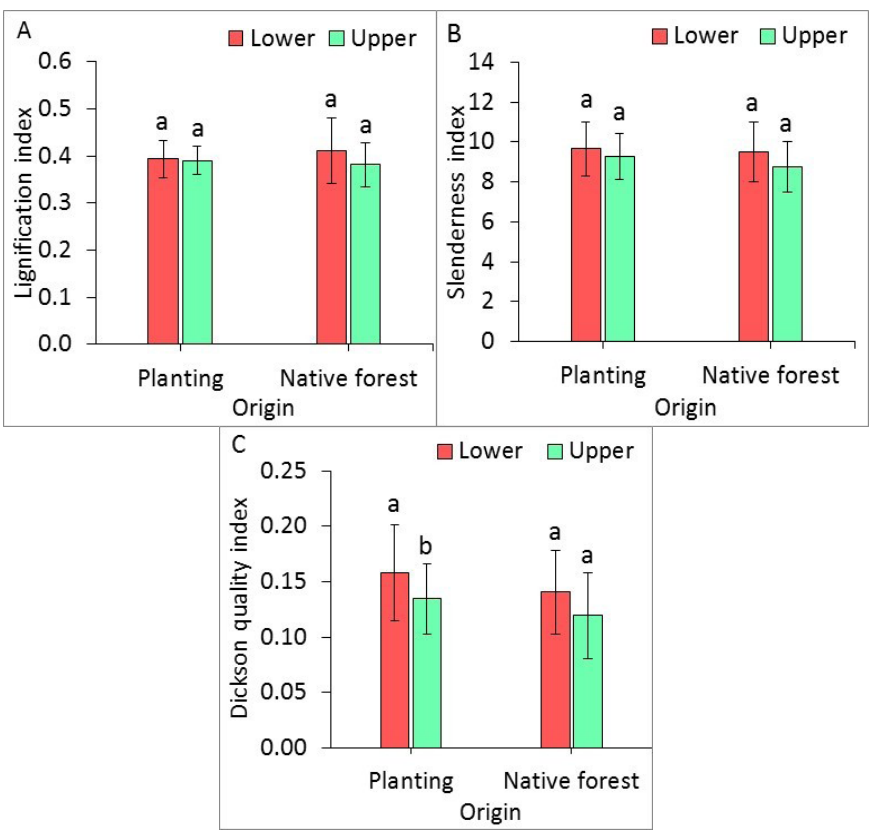

Figure 6. Mean $( \pm S D)$ of lignification index $(A)$, slenderness index (B), and Dickson quality index (C) of Bertholletia excelsa seedlings produced with seeds from planting and native forest at 180 days after sowing in Puerto Maldonado, Peru. Letters indicate significant differences $(p<0.05)$ in ANOVA with the F test.

tree, especially the number of ovules and their fecundation rate. As much the number of fecundated ovules as much the time that fruit will be linked to the matrix tree, which increases their nuts biomass (Moritz, 1984). Environmental factors such as rain, wind, and temperature have strong influence on the plant fecundation. Knowledge on how environmental factors influence plant fecundation and germination is essential for seedling production. Thus, these factors can be controlled and managed in order to optimize percentage, speed, and evenness of germination that can consequently result in the production of more vigorous seedlings for field planting.

One of the hypotheses that can explain the differences in fruit size of $B$. excelsa found in this study between the native forest and the planted one is related to age and consequently to the trees size (especially stem and crown diameter). Even with no information on the actual age of the sampled Brazil nut trees in the native forest, it is reasonable to affirm that they are centenary individuals (the big size trees), while the planting trees are not older than 15 years (the small size trees). These morphometric factors of a given individual can regulate fruit size and fruit quantities produced by a tree as well as the seeds quantities inside a fruit. Fruit production of Brazil nut trees is highly variable and the main factors that determine this variability are: tree size (mainly stem diameter), crown attributes, sociological position, liana infestation, time variation, climate factors, genetic factors, and ecological interactions with pollinators, predators, and dispersers (Zuidema \& Boot, 2002; Wadt et al., 2005; Kainer et al., 2007).

In a study carried out by Tonini et al. (2008), it was observed a significant relation between seed production with seed length, diameter, shape, and sociological position of Brazil nut trees. The authors still observed that the crown variables (diameter and position) explained the higher variability on seeds production. However, diameter at breast height (DBH) was the variable that best explained such variation. Wadt et al. (2005) found that the bigger the stem diameter is, the better is the sociological position and crown shape and the higher the seeds production of Brazil nut is. Kainer et al. (2007) observed that the stem diameter was the variable with highest importance and explained $56.5 \%$ of the fruits production variation.

\section{Seedling emergence and initial growth}

The distribution of germination over time in polynomial curves (Figures $3 \mathrm{~A}$ and $3 \mathrm{~B}$ ) followed the standard model of germination found in most tree species (Czabator, 1962). This kind of germination is featured by three different periods: initial, where the increase in germination percentage is slow (water absorption time), followed by a period of higher germination, and finally a period of decrease in the germination rates (Dionisio et al., 2017). The long period demanded for germination of $B$. excelsa seeds found in this study (30-160 days) can be related to their genetic variability and level of the embryo maturation of the sampled seeds. In tree species, reproductive characteristics favor the maintenance of high levels of genetic variability (Sebbenn, 2002). Seeds are a source of genetic variability, especially when collected over a great number of matrix trees in native forests. The high percentage of $B$. excelsa seeds with incomplete germination can be due to the fact that they do not clearly present a radicle. As a consequence, it is demanded more time for germination, since a radicle needs to be developed. $B$. excelsa usually has a germination process that lasts up to five months after sowing, reaching a germination percentage higher than 70\% (Müller, 1982; Silva et al., 2009). In this study, like in Frazão et al. (1984), after 180 days there were still viable seeds left in the seedbed.

In seeds with morphological dormancy (MD), embryos are small (underdeveloped) and differentiated, i.e. cotyledon(s) and hypocotyl-radicle can be distinguished (Baskin \& Baskin, 2014). Embryos in seeds with MD are not physiologically dormant and do not require a dormancybreaking pretreatment in order to germinate. They therefore simply need time to grow up to full size and then germinate (radicle protrusion). The dormancy period is the time elapsed between incubation of fresh seeds and radicle emergence.

Physical dormancy (PY) is caused by one or more waterimpermeable layers of palisade cells in the seed or fruit coat (Baskin et al., 2000). In these cases, hydration and the consequent dormancy interruption is often related to openings formation in the specialized anatomical structures as the hilum, which is a structure over the seed surface that causes a decrease in the seed resistance to water entrance (Baskin \& Baskin 2004; Cardoso, 2009; Baskin \& Baskin, 2014). The physiological dormancy (PD) is caused by inhibitory mechanisms involving metabolic processes and the 
development control. In PD, many mechanisms take place not only inside the embryo, but in the tissues and side structures as well, such as the integument and endosperm. According to Baskin \& Baskin (2004), PD is a kind of dormancy where the presence of inhibitory substances or absence of promoting substances prevents germination. It can be divided in deep, intermediate, or superficial. Deep PD occurs in species that demand a long period with low temperatures to be broken. The difference between intermediate and superficial DP is in the absence of embryo growth or through the formation of abnormal seedlings, even when the embryo gets isolated from the seed. Intermediate and superficial are the most common types of PD, with the embryo isolation necessary in order to the formation of normal seedlings being possible (Vivian et. al., 2008).

Several hypotheses have been presented to explain the slow and irregular germination of $B$. excelsa. Among these, there are the chemical dormancy through the presence of chemical inhibitors (Kainer et al., 1999a) and the morphological dormancy due to embryo immaturity (Kainer et al., 1999b). This kind of dormancy is commonly found in tree species and occurs because of the immature embryo or the presence of physiological inhibition, which prevents the embryo development (Fowler \& Bianchetti, 2000). Therefore, even removing the integument, many viable seeds do not germinate. Camargo (1997) reports that the $B$. excelsa almond, during its maturation and dispersal, does not present tissues in advanced stages of cell differentiation. This can partially explain the slow germination process of the species. Nevertheless, none of these hypotheses were ever tested, which makes difficult to clearly understand the germination process of $B$. excelsa. In a study including 16 matrixes of $B$. excelsa in the Roraima state, Brazil, Pedrozo et al. (2017), after 15 days observed $77.8 \%$ of emergence, $9.3 \%$ of incomplete germination, and $12.1 \%$ of degraded seeds. The authors used a method of slow scarification that consisted in storing seeds in woody boxes filled by wet sand strata. Seeds were stored for 60 days before the start of the experiment and the evaluation time of emergence was 150 days.

Five months after sowing, seedlings reached the optimal height for planting in the field $(30 \mathrm{~cm})$. According to Müller (1981), B. excelsa seedlings are suitable for planting in the field when they attain nearly $25 \mathrm{~cm}$ in height and 16 leaves, which usually occur in 4-8 weeks after seedlings transplanting. Precocity and uniformity on seedlings emergence are advantageous features of seedlings production, so the more time seeds demand to germinate and remain in the initial development phase the more vulnerable they will be to adverse conditions. Pedrozo et al. (2017) point out that, due to the high variability in emergence indexes of seedlings from different matrixes, seedlings from seeds sowed at the same time can present differences in the emergence time up to four months. Such variation in the seedlings initial development can be linked to different genetic backgrounds among seedlings as well as environmental causes, germination time, size, and amount of seed reserves (Dlamini, 2010).

\section{Seedlings quality indexes}

The lignification index indicates the lignification level of shoot and root tissues of seedlings belonging to woody species under stress. Physical stimuli applied as stem flexion make seedlings start morphometric responses usually linked to height reduction, increase in the stem collar diameter, and increase in dry mass of the root tissue (Dranski et al., 2015). The plant response to these physical stimuli is defined as thigmomorphogenesis, which occurs in phases where seedlings are more able to resist to mechanical injuries (Jaffe, 1973). Hence, there is a relation between seedlings tissues lignification and the growth and survival performance of seedlings in the field (Dranski et al. 2015). With no significant difference in the SDM/RDM relation, seedlings present similar patterns of dry mass distribution between the two organs (Marana et al., 2015; Siqueira et al., 2018). The SDM/ RDM relation indicates a biomass distribution between the shoot and root system (Siqueira et al., 2018). This uniform distribution of dry mass between the shoot and root system makes possible for the seedling an adequate development with lower tipping risks once planted in the field.

According to Mexal \& Landis (1990), the seedling quality indexes are good predictors of the future seedling size in the field, however they are not efficient indicators on future seedling survival. The seedling stage is possibly the most vulnerable stage in the life cycle of a plant. Under natural conditions, seedling establishment and subsequent reproductive success can be impaired due to multiple reasons: untimely emergence, germination at inconvenient depths and emergence under environments with high competitive pressure to survive or leave offspring. Hence, seeds must have effective mechanisms to detect changes in environmental conditions in order to be able to establish for the development of further life stages (Batlla \& Benech-Arnold, 2014).

\section{Conclusions}

Most of the seeds were present in the lower position inside the fruit, regardless of their origin from planting or native forest.

Seed position inside the fruit had no influence on the germination percentage of Bertholletia excelsa seeds collected both in fruits originated from planting and native forest.

Regarding the fruits, those originated from native forest presented larger length, diameter, mesocarp thickness, and weight.

Seedlings produced with seeds from planting and from the lower part of the fruit presented higher quality.

\section{Literature Cited}

Ali, H.; Tanveer, A.; Nadeem, M.; Asghar, H.; Javaid, M. Germination ecology of Rhynchosia capitata: an emerging summer weed in Asia. Planta Daninha, v. 31, n. 2, p. 249-257, 2013. https://doi. org/10.1590/S0100-83582013000200002. 
Auca, E. C.; Dionisio, L. F. S.; Bardales-Lozano, R. M.; Schwartz, G. Propagation of Brazil nut (Humb. y Bonpl) seedlings using seeds in mini-greenhouses. Revista Agro@mbiente On-line, v. 12, n. 4, p. 300-313, 2018. https://doi.org/10.18227/1982-8470ragro. v12i4.5222.

Baskin, C. C.; Baskin, J. M. A classification system for seed dormancy. Seed science research, v. 14, n. 1, p. 1-16, 2004. https://doi. org/10.1079/SSR2003150.

Baskin, C. C.; Baskin, J. M. Seeds: ecology, biogeography, and evolution of dormancy and germination. 2.ed. San Diego: Academic Press, 2014. 1600p.

Baskin, J. M.; Baskin, C. C.; Li, X. Taxonomy, ecology, and evolution of physical dormancy in seeds. Plant Species Biology, v. 15, n. 2, p. 139152, 2000. https://doi.org/10.1046/j.1442-1984.2000.00034.x.

Batlla, D.; Benech-Arnold, R. L. Weed seed germination and the light environment: Implications for weed management. Weed Biology and Management, v. 14, n. 2, p. 77-87, 2014. https://doi. org/10.1111/wbm.12039.

Borella, D. R.; Silva, A. C.; Souza, A. P.; Bouvie, L.; Nogueira, L. D. S.: Pereira, C. D. L.; Silva, M. A. L. V. Biometria de frutos e sementes da castanheira-do-Brasil da região Médio-Norte do Mato Grosso. Nativa, v.5, n. especial, p.483-490, 2017. https://doi. org/10.5935/2318-7670.v05nespa04.

Borges, F. A.; Tonini, H.; Baldoni, A. B.; Botelho, S. C. C. Tamanho da amostra para estimar produção de sementes de castanheiras nativas em Mato Grosso. Nativa, v.4, n.3, p.66-169. 2016. https:// doi.org/10.14583/2318-7670.v04n03a09.

Camargo, I. P. Estudos sobre a propagação da castanheira-do-brasil (Bertholletia excelsa Humb. \& Bompl.). Lavras: Federal University of Lavras, 1997. 127p. PhD Dissertation. http://repositorio.ufla. br/handle/1/2061. 28 Jul. 2018.

Cardoso, V. J. M. Conceito e classificação da dormência em sementes. Oecologia Brasiliensis, v. 13, n. 4, p. 619-631, 2009. https://doi. org/10.4257/oeco.2009.1304.06.

Caron, B. O.; Souza, V. Q.; Cantarelli, E. B.; Manfron, P. A.; Behling, A.; Eloy, E. Crescimento em viveiro de mudas de Schizolobium parahyba (Vell.) S. F. Blake. Submetidas a níveis de sombreamento. Ciência Florestal v.20, n.4, p.683-689, 2010. https://doi.org/10.5902/198050982427.

Cosmo, N. L.; Gogosz, A. M.; Rego, S. S.; Nogueira, A. C.; Kuniyoshi, Y. S. Morfologia de fruto, semente e plântula, e germinação de sementes de Myrceugenia euosma (O. Berg) D. Legrand (Myrtaceae). Floresta v.47, n.4, p.479-488, 2017. https://doi. org/10.5380/rf.v47i4.46933.

Costa, M. G.; Tonini, H.; Mendes Filho, P. Atributos do Solo Relacionados com a Produção da Castanheira-do-Brasil (Bertholletia excelsa). Floresta e Ambiente, v. 24, p. e20150042, 2017. https://doi.org/10.1590/2179-8087.004215.

Czabator, F. J. Germlnatlon value: an index combining speed and completeness of pine saed germination. Forest Science, v. $8, n$. 4, p. 386-396, 1962.

Dionisio, L. F. S.; Smiderle, O. J.; Montenegro, R. A.; Martins, W. B. R., Simões, P. H. O.; Araújo, D. G. Emergência e crescimento inicial de plântulas de Swietenia macrophylla (King) em função da posição da semente e presença do endocarpo. Revista de Ciências Agrárias, v. 60, n. 2, p. 125-130, 2017. https://doi.org/10.4322/ rca.10573.
Dlamini, C. S. Provenance and family variation in germination and early seedling growth in Sclerocarya birrea sub-species caffra. Journal of Horticulture and Forestry v.2, n.9, p.229235. 2010. https://academicjournals.org/journal/JHF/articleabstract/2B702206189. 22 Jun. 2018.

Dranski, J. A. L.; Malavasi, U. C.; Malavasi, M. M. Relationship between lignin content and quality of Pinus taeda seedlings. Revista Árvore, v. 39, n.5, p. 905-913, 2015. https://doi. org/10.1590/0100-67622015000500013.

Duryea, M.L. Importance to reforestation. In: Duryea, M.L. (Ed.). Proceedings: Evaluating seedling quality: principles, procedures, and predictive abilities of major tests. Corvallis: Oregon State University; Forest Research Laboratory, 1985. p. 1-6. https://rngr. net/publications/evaluating/PDF.2003-10-27.2237. 19 Jul. 2018.

Ebrahimi, E.; Eslami, V. Effect of environmental factors on seed germination and seedling emergence of invasive Ceratocarpus arenarius. Weed Research, v. 52, n.1, p. 50-59, 2011. https://doi. org/10.1111/j.1365-3180.2011.00896.x.

Fowler, J. A. P.; Bianchetti, A. Dormência em sementes florestais. Colombo: Embrapa Florestas, 2000. 27p. (Embrapa Florestas. Documentos, 40). https://www.infoteca.cnptia.embrapa.br/ bitstream/doc/290718/1/doc40.pdf. 22 Jun. 2018.

Frazão, D. A. C.; Müller, C. H.; Figueiredo, F. J. C.; Muller, A. A.; Pereira, L. A. F. Escarificação química na emergência de sementes de castanha-do-brasil (Bertholletia excelsa, HBK). Revista Brasileira de Sementes, v.6, n.1, p.83-90, 1984. https://www.researchgate. net/publication/267223790. $07 \mathrm{Jul} .2018$.

Jaffe, M. J. Thigmomorphogenesis: the response of plant growth and development to mechanical stimulation with special reference to Bryonia dioica. Planta v.114, n.2, p.143-156, 1973. https://doi. org/10.1007/BF00387472.

Kainer, K. A.; Wadt, L. H. O.; Staudhammer, C. L. Explaining variation in Brazil nut fruit production. Forest Ecology and Management, v. 250, n.3, p. 244-255, 2007. https://doi.org/10.1016/j.foreco.2007.05.024.

Kainer, K. A.; Duryea, M. L.; Malavasi, M. M.; Duryea, M. L.; Silva, E. Brazil nut (Bertholletia excelsa) seed characteristics, preimbibition and germination. Seed Science and Technology, v.27, n.2, p.731-745, 1999b. https://www.researchgate.net/ publication/286726170. $05 \mathrm{Jul}$. 2018.

Kainer, K. A.; Duryea, M. L.; Malavasi, M. M.; Silva, A. R.; Harrison, J. Moist storage of Brazil nut seeds for improved germination and nursery management. Forest Ecology and Management v.116, n.1-3, p.207-217. 1999a. https://doi.org/10.1016/S03781127(98)00461-7.

Marana, J. P.; Miglioranza, É.; Fonseca, P. É. Qualidade de mudas de jaracatiá submetidas a diferentes períodos de sombreamento em viveiro. Revista Árvore, v. 39, n. 2, p. 275-282, 2015. https://doi. org/10.1590/0100-67622015000200007.

Mexal, J. G. and Landis T. D. Target seedling concepts: height and diameter. In: Rose, R.; Campbell, S.J.; Landis, T. D. (Eds.). Proceedings: Western Forest Nursery Association Target seedlings symposium. Fort Collins: U.S. Department of Agriculture; Forest Service; Rocky Mountain Forest and Range Experiment Station, 1990. Chap. 3, p.105-119. (General Technical Report RM-200). https://rngr.net/publications/proceedings/1990/mexal.pdf. 31 Mai. 2018. 
Moritz, A. Estudos biológicos da floração e frutificação da castanhado-Brasil (Bertholletia excelsa H. B. K.). Belém: Embrapa-CPATU, 1984. 84p. (Embrapa-CPATU. Documentos, 29). https://www. infoteca.cnptia.embrapa.br/handle/doc/387228. 22 Jun. 2018.

Müller, C. H. Castanha-do-brasil: estudos agronômicos. Belém: Embrapa-CPATU, 1981. 25p. (Embrapa-CPATU. Documentos, 1). http://www.infoteca.cnptia.embrapa.br/infoteca/handle/ doc/379778. 22 Jun. 2018.

Müller, C. H. Quebra da dormência da semente e enxertia em castanha-do-brasil. Belém: Embrapa-CPATU, 1982. 40p. (Embrapa-CPATU. Documentos, 16) https://www.infoteca.cnptia. embrapa.br/handle/doc/381176. 22 Jun. 2018.

Pedrozo, C. Costa, E. K. L.; Oliveira, V. X. A.; Batista, K. D.; Smiderle, O. J.; Albuquerque, T. C. S. Emergência de plântulas e desenvolvimento de mudas de matrizes selecionadas de castanha-do-Brasil. Boa Vista: Embrapa Roraima. 2017. 21 p. (Embrapa Roraima. Boletim de Pesquisa e Desenvolvimento, 44). http://www.infoteca. cnptia.embrapa.br/infoteca/handle/doc/1074259. 29 Jun. 2018.

Rocha, V. D.; Lima, J. S.; Bispo, R. B.; Cochev, J. S.; Rossi, A. A. B. Caracterização biométrica de frutos e sementes de castanha-dobrasil na Amazônia Mato-Grossense. Enciclopédia Biosfera v.13, n.24, p.186-195, 2016. http://www.conhecer.org.br/enciclop/2016b/ agrarias/caracterizacao\%20biometrica.pdf. 05 Jul. 2018.

Salomão, R. P. Castanheira-do-Brasil recuperando áreas degradadas e provendo alimento e renda para comunidades da Amazônia Setentrional. Boletim do Museu Paraense Emílio Goeldi. Ciências Naturais v.1, n.2, p.65-78, 2006. http://scielo.iec.gov.br/scielo. php?script=sci_arttext \&pid=S1981-81142006000200005\&lng=p t\&nrm=iso\&tlng=pt. 22 Jun. 2018.

Santos, R.; Campos, T. D.; Martins, K.; Wadt, L. D. O. Estrutura genética de duas populações naturais de Bertholletia excelsa Bonpl. sob exploração no Vale do Rio Acre. Biota Amazônia, v. 7, n. 3, p. 3740, 2017. https://doi.org/10.18561/2179-5746/biotaamazonia. v7n3p37-40.

Sebbenn, A. M. Número de árvores matrizes e conceitos genéticos na coleta de sementes para reflorestamentos com espécies nativas. Revista do Instituto Florestal v.14, n.2, p.115-132, 2002. http:// www.iflorestal.sp.gov.br/RIF/RevistalF/RIF14-2/RIF14-2_115132.pdf. 28 Jul. 2018.

Silva, A. N.; Coelho, M. F. B.; Guimarães, S. C.; Albuquerque, M. C. F. Germinação de sementes de castanheira-do-pará armazenadas em areia úmida. Pesquisa Agropecuária Brasileira v.44, n.11, p.1431-1436, 2009. https://doi.org/10.1590/S0100204X2009001100009.
Siqueira, D. P.; Carvalho, G. C. M. W.; Barroso, D. G.; Marciano, C. R. Lodo de esgoto tratado na composição de substrato para produção de mudas de Lafoensia glyptocarpa. Floresta v.48, n.1, p.277-284, 2018. https://doi.org/10.5380/rf.v48i2.55795.

Sujii, P. S.; Martins, K.; Wadt, L. H. O.; Azevedo, V. C. R.; Solferini, V. $\mathrm{N}$. Genetic structure of Bertholletia excelsa populations from the Amazon at different spatial scales. Conservation Genetics v.16, n.4, p. 955-964, 2015. https://doi.org/10.1007/s10592-0150714-4.

Tanveer, A.; Mumtaz, K.; Javaid, M.; Chaudhry, M.; Balal, R. M.; and Khaliq, A. Effect of ecological factors on germination of horse purslane (Trianthema portulacastrum). Planta Daninha, v. 31, n.3, p. 587-597, 2013. https://doi.org/10.1590/S010083582013000300011.

Tanveer, A.; Arshad, M. S.; Ayub, M.; Javaid, M. M.; Yaseen, M. Effect of temperature, light, salinity, drought stress and seeding depth on germination of Cucumis melo var. agrestis. Pakistan Journal of Weed Science Research, v. 18, n.4, p. 445-459, 2012. https:// www.wssp.org.pk/weed/ojs/index.php/pjwsr/article/view/401. 21 Jun. 2018.

Tonini, H.; Kaminski, P. E.; Costa, P. Relação da produção de sementes de castanha-do-brasil com características morfométricas da copa e índice de competição. Pesquisa Agropecuária Brasileira, v. 43 , n. 11, p. 1509-1516, 2008. https://doi.org/10.1590/S0100204X2008001100009.

Vivian, R.; Silva, A. A.; Gimenes, J. M.; Fagan, E. B.; Ruiz, S. T.; Labonia, V. Dormência em sementes de plantas daninhas como mecanismo de sobrevivência - breve revisão. Planta Daninha, v. 26 , n. 3, p. 695-706, 2008. https://doi.org/10.1590/S010083582008000300026.

Wadt, L. H. O.; Faustino, C. L.; Staudhammer, C. L.; Kainer, K. A.; Evangelista, J. S. Primary and secondary dispersal of Bertholletia excelsa: Implications for sustainable harvests. Forest Ecology and Management, v. 415-416, p. 98-105, 2018. https://doi. org/10.1016/j.foreco.2018.02.014.

Wadt, L. H. O.; Kainer, K. A.; Gomes-Silva, D. A. P. Population structure and nut yield of a Bertholletia excelsa stand in Southwestern Amazonia. Forest Ecology and Management, v.211, n.3, p.371384, 2005. https://doi.org/10.1016/j.foreco.2005.02.061.

Zuidema, P. A.; Boot, R. G. A. Demography of the Brazil nut tree (Bertholletia excelsa) in the Bolivian Amazon: impact of seed extraction on recruitment and population dynamics. Journal of Tropical Ecology, v. 18, n.1, p. 1-31, 2002. https://www.jstor. org/stable/3068653. 10 Jul. 2018. 